Documentación de las Ciencias de la Información ISSN: 0210-4210

https://doi.org/10.5209/dcin.63672

\title{
Sinergias entre expresión y contenido en los filmes de temática social de Nieves Conde: el caso de Todos somos necesarios (1956)
}

\author{
Rubén Higueras Flores ${ }^{1}$
}

Recibido: 14 de marzo de 2019 / Aceptado: 29 de julio de 2019

Resumen. El presente texto pretende exponer el fértil aparato significante desplegado en los largometrajes de temática social dirigidos por José Antonio Nieves Conde mediante el análisis textual de un filme paradigmático como Todos somos necesarios. Para ello, evidenciaremos la manera en que los mecanismos enunciativos forjan y refuerzan el discurso del texto, revelando un dispositivo enunciativo de inusitada riqueza y singular hibridez, cuyas imágenes se aproximan a un registro aparentemente realista tomando como referencia opciones estéticas paradójicamente opuestas en su alto grado de estilización.

Palabras clave: Cine español, Nieves Conde, Análisis fílmico, Forma fílmica

[en] Synergies between expression and content in the social themed films of Nieves Conde: the case of Todos somos necesarios (1956)

Abstract. The present text intends to expose the fertile significant apparatus displayed in the social themed feature films directed by José Antonio Nieves Conde through the textual analysis of a paradigmatic film such as Todos somos necesarios, demonstrating the way in which the enunciative mechanisms forge and reinforce the discourse of the text, revealing an enunciative device of unusual richness and singular hybridity, whose images approach an apparently realistic register, taking paradoxically opposite aesthetic options as a reference in their high degree of stylization.

Key words: Spanish cinema, Nieves Conde, Film analysis, Film form

Sumario: 1. Introducción; 2. Todos somos necesarios (1956); 2.1. Un país de prisioneros; 2.2. Liberalismo; 2.3. Sacrificios por el bien de la comunidad; 2.4. Redundancia; 3. Conclusiones; 4. Bibliografía

Cómo citar: Higueras Flores, R. (2019). Sinergias entre expresión y contenido en los filmes de temática social de Nieves Conde: el caso de Todos somos necesarios (1956) en Documentación de las Ciencias de la Información, 42, 89-103.

\section{Introducción}

Aunque la elaborada escritura fílmica de Nieves Conde constituye un valor primordial de su filmografía, fueron los cuantiosos problemas y encontronazos con el gobierno franquista y/o la Iglesia ocasionados por sus filmes de corte social los que

\footnotetext{
1 Facultad de Ciencias de la Información. UCM

ruben.higueras@ucm.es
} 
aportaron relevancia historiográfica a su cine. Sin embargo, tanto Surcos como El inquilino y Todos somos necesarios (filme que no padeció los contratiempos que acosaron a los dos primeros títulos) presentan un dispositivo enunciativo de inusitada riqueza, hasta el extremo que podemos afirmar que sus imágenes se aproximan a un registro aparentemente realista tomando como referencia opciones estéticas paradójicamente opuestas en su nivel de estilización.

Los tres textos están articulados a partir de una idea medular, manifestada explícitamente en la superficie argumental del texto, que guía el despliegue formal y narrativo de las estrategias enunciativas que apuntalan el discurso, confeccionando un tejido textual coherente en el que cada pieza (secuencia) de la estructura episódica reincide en ella. Nuestra pretensión a lo largo del presente artículo será la de analizar el fértil aparato significante desplegado en uno de esos textos, tratando de exponer de qué manera los mecanismos enunciativos forjan y refuerzan (e incluso comentan) el discurso. Tratamos, en esencia, de abordar la dialéctica entre los dos planos del signo, expresión y contenido, que Hjelmslev formulara en el campo de la lingüística, trasladándola a la gramática cinematográfica mediante un texto filmico de la singularidad de Todos somos necesarios. ${ }^{2}$

\section{Todos somos necesarios (1956)}

Todos somos necesarios es una película de tesis. Su trama se construye alrededor de una idea que condiciona la práctica totalidad de los elementos narrativos y argumentales del filme (especialmente, la caracterización de los personajes y los conflictos que entre ellos se establecen), supeditados al eficiente trazado de un único itinerario de lectura del texto fílmico que asegure la correcta interpretación del mensaje por parte del espectador. Lo relevante de tal operación radica en la rotunda complementariedad entre los dispositivos narrativos y una retórica formal que, mediante la configuración plástica del espacio, la planificación y el montaje, elabora el discurso.

\subsection{Un país de prisioneros}

Conocida es la circunstancia de que la censura obligó a suprimir el final originalmente escrito para Surcos, en el que la familia protagonista, al tomar el tren que les llevará de regreso al ámbito rural, se cruzaba con otra familia que llegaba a la ciudad desde el campo con la esperanza de encontrar trabajo y prosperar, tal y como los Pérez habían hecho al inicio del metraje. Se generalizaba así lo que en el filme había aparecido como caso concreto: el éxodo hacia la urbe de los campesinos y su complicada adaptación a la vida en la ciudad. Todos somos necesarios parece recuperar esa idea que dota de carácter iterativo, general y cíclico a la peripecia de sus protagonistas: al disponerse a subir al tren que ha de conducirles hacia su reinserción en la sociedad, el trío de expresidiarios protagónico -Julián (Alberto Closas), Iniesta (Folco Lulli) y Nicolás (Ferdinand Anton)- se cruza con una pareja de reos que se apea de éste para ser conducida por los guardias civiles que la escoltan a la prisión que los primeros acaban de abandonar.

Empero, la libertad que acaban de recobrar los tres personajes resulta no ser tal, pues pronto descubren que su pasado penitenciario estigmatiza su presente y condena su futuro. «La cárcel ya va con nosotros para siempre», afirma Julián a los pocos se-

2 Hjelmslev, Louis (1971). Prolegómenos a una teoría del lenguaje. Madrid: Gredos. 
gundos de haber abandonado el penal. Los protagonistas (y el espectador) serán conscientes de ello en cuanto pretendan integrarse en esa suerte de microcosmos social que constituye el interior del tren. El plano en el que acontece el primer encuentro entre los protagonistas y algunos de los pasajeros del ferrocarril muestra la confrontación visual de ambos mundos (el de los expresidiarios y el de la sociedad en cuyo seno aspiran a reintegrarse). El tren se detiene en la estación en cuyo andén espera el trío protagonista y la esposa de Nicolás, Alicia (Mirella Uberti). Frente a éstos queda la ventana de un vagón, en cuyo interior se halla un grupo de pasajeros. Los dos conjuntos de personajes se observan a través del cristal que los separa (metáfora de las diferencias -sociales, económicas, ideológicas, vitales- que los distancian) con una mezcla de curiosidad e inquietud hacia quienes consideran como diferentes. [Fig. 1].

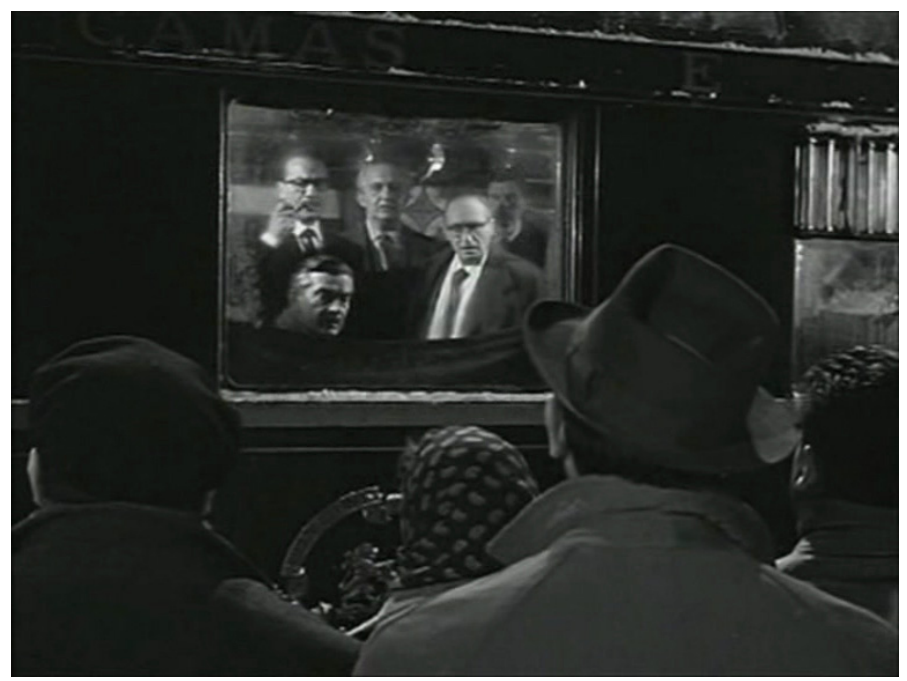

Al acceder al pasillo de uno de los vagones, un plano filmado desde la posición de los antiguos presidiarios muestra cómo la totalidad de las recelosas (a un paso de resultar acusadoras) miradas de los pasajeros se dirige hacia ellos. La subjetividad de la imagen conlleva que el espectador se convierta en receptor de tales miradas, quien experimenta la violencia y la tensión de la situación al verse en la piel de los protagonistas. Esta hosca actitud ante la aparición del trío protagónico presagia la dificultad que estos encontrarán para lograr acomodo en los departamentos del tren ante el rechazo del resto de pasajeros a que se sienten junto a ellos. Los protagonistas permanecen, pues, en una suerte de celda figurada delineada por los prejuicios, la incomprensión y la desconfianza de sus semejantes. Pero he aquí que estos aparecen igualmente retratados como prisioneros de las dinámicas y los convencionalismos sociales. Tanto unos como otros se verán sometidos a un segundo aprisionamiento al quedar atrapados en el interior del ferrocarril, giro dramático que los obligará a interactuar y a enfrentarse con sus prejuicios. ${ }^{3}$ Así, España (representada metafórica

3 En este sentido, podría esbozarse una similitud entre El ángel exterminador (Luis Buñuel, 1962) y el filme que nos ocupa, pero, aunque ambas obras se sirvan del encierro espacial de sus personajes para explicitar determinadas dinámicas sociales, sus objetivos son radicalmente distintos, por lo que no lo consideramos oportuno ni operativo. 
y metonímicamente por el tren) aparece retratada como un país de individuos atrapados, víctimas de sus prejuicios o de los del prójimo.

Como puede inducirse a tenor de lo comentado, a lo largo del metraje priman las secuencias en interiores. En muchos planos, la composición parece aprisionar a los personajes entre los límites del encuadre. El uso sistemático de la profundidad de campo se complementa con unas composiciones que rentabilizan plásticamente las líneas de fuga de la imagen, disponiendo a los personajes en sutiles diagonales. ${ }^{4} \mathrm{El}$ techo de los vagones, omnipresente en el campo visual, contribuye a la consecución de una sutil sensación de encierro en el espectador. [Figs. 2 a 4].
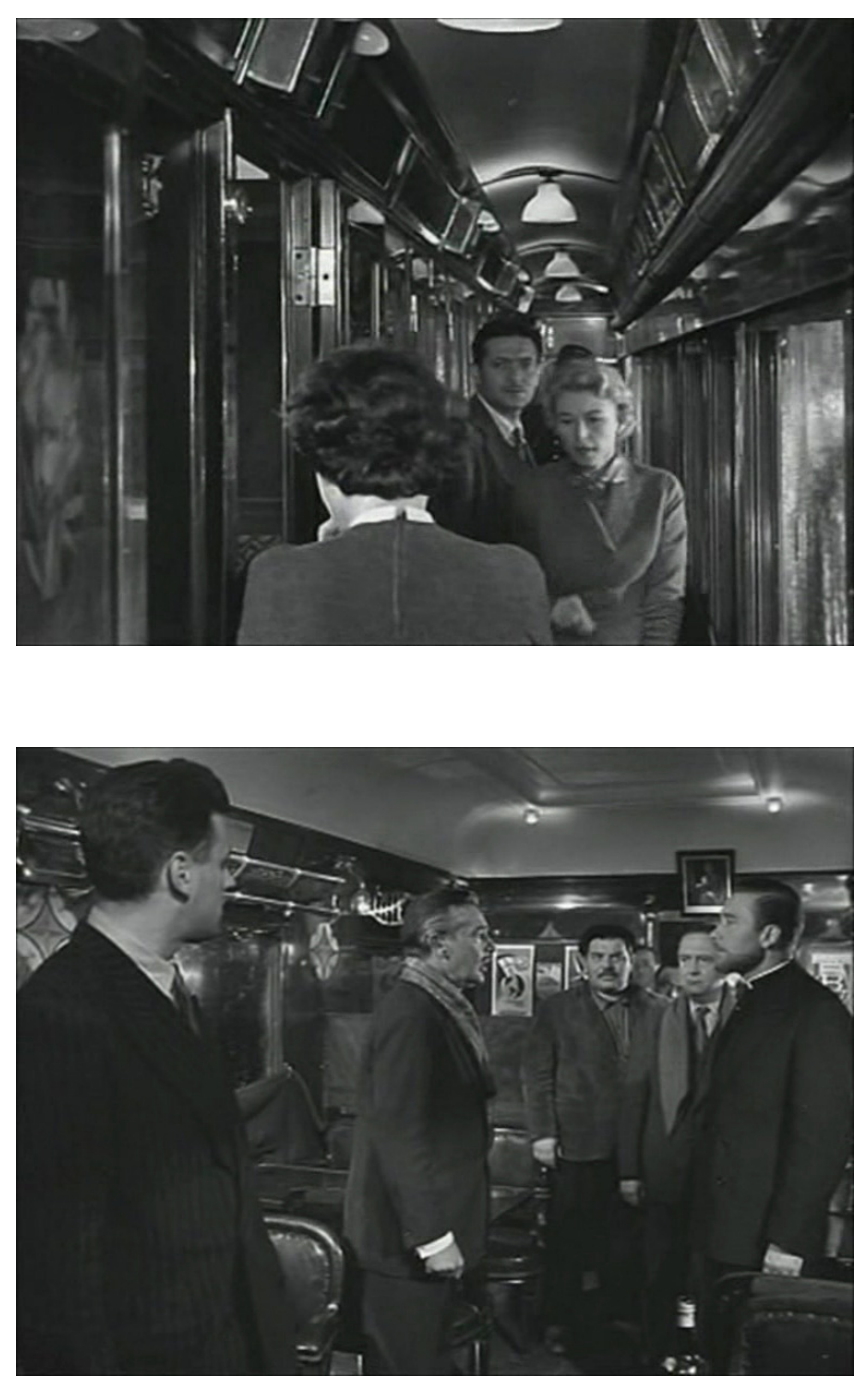

$4 \quad$ El uso de ópticas angulares para garantizar la profundidad de campo en las imágenes complicó el trabajo de iluminación y de puesta en escena durante el rodaje: «La iluminación y la escenificación fueron complejas por el constante empleo de grandes angulares, para así "ver" a todos los actores en los encuadres», recordaba el cineasta. En Llinás, Francisco (1995). José Antonio Nieves Conde. El oficio de cineasta, Valladolid: Seminci, p. 101. 


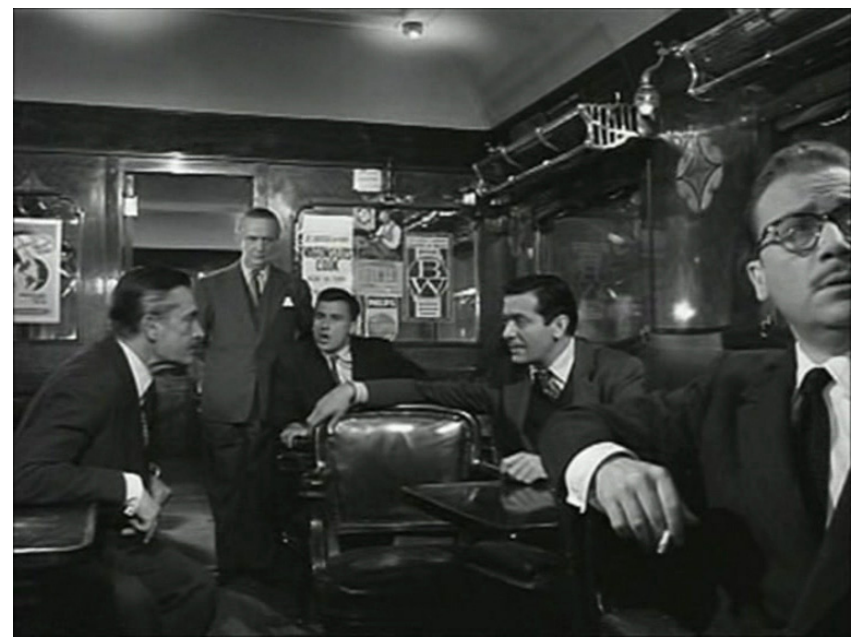

El plano inicial instaura ya el motivo de la reclusión: varias franjas de barrotes dispuestas en diferentes planos visuales (la conjunción de la perspectiva y la profundidad de campo logra que se superpongan unas encima de otras) componen un enrejado que cifra plásticamente la idea de confinamiento. ${ }^{5}$ Mientras los títulos de crédito se sobreimpresionan en pantalla, dos filas de figuras en sombra pertenecientes a presidiarios anónimos desfilan ante el espectador. Aparece en imagen el título del filme. Con tal proceder, se persigue la universalización de la peripecia dramática de los personajes, así como de la tesis del largometraje que el título en pantalla enuncia con literalidad. [Figs. 5, 6].

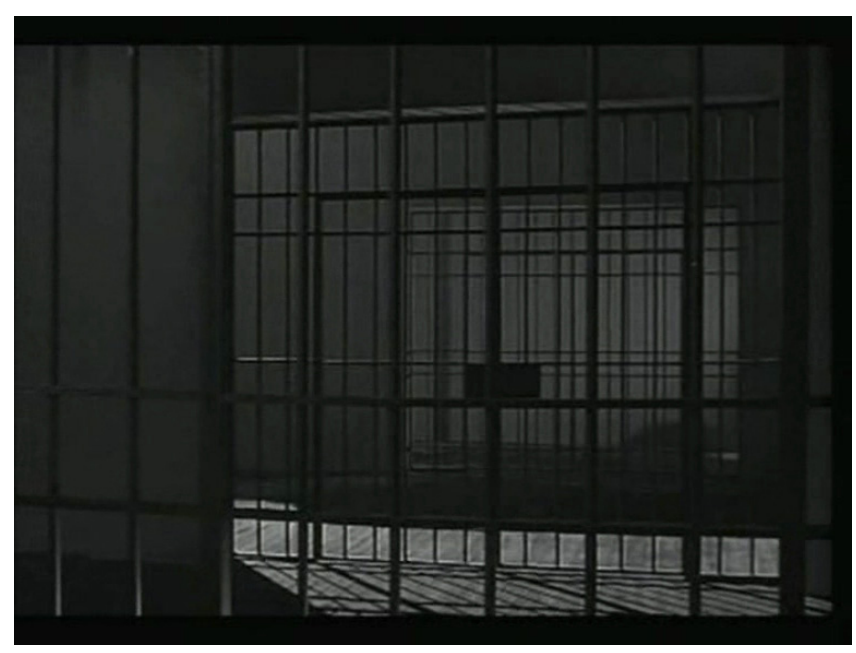

5 Con recurrencia, aparecen una serie de marcos de puertas acristaladas y ventanas que remiten a celdas; reencuadrando puntualmente a algún personaje (por ejemplo, a Iniesta en su llegada a la estación tras recorrer diez kilómetros bajo la nieve). 


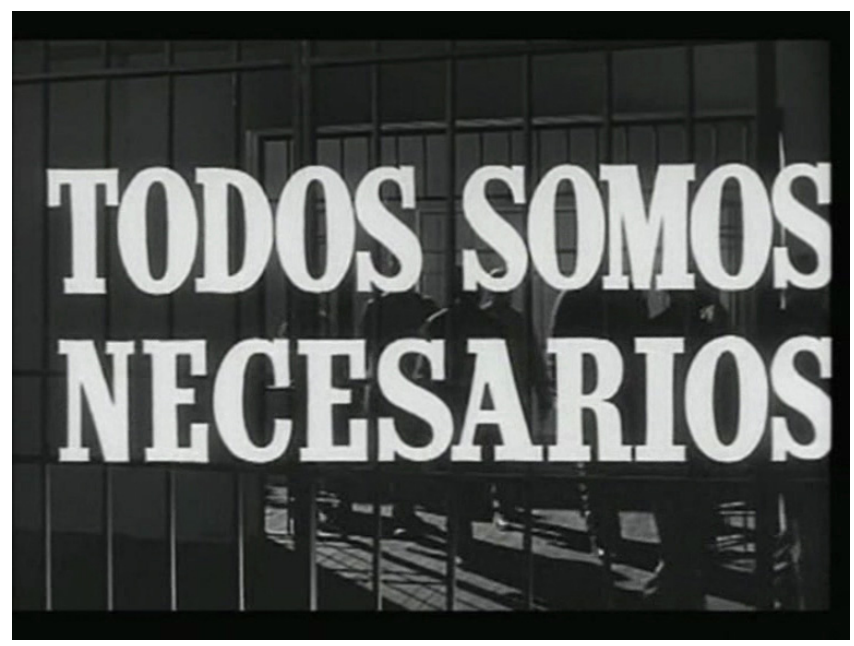

En el heterogéneo grupo de pasajeros, que personifica a la totalidad de la sociedad española de la época, encontramos sujetos de clases sociales radicalmente opuestas - desde una familia proveniente del ámbito rural de escasos recursos económicos ${ }^{6}$ hasta un potentado empresario-, así como representantes de lo gubernamental (el policía) y del clero (un cura misionero). El unánime deseo de éxito de la imprevista y vital operación a la que un infante ha de ser sometido a bordo del tren será lo que una, si bien momentáneamente, a tan disímil conjunto de personajes. La situación sobrevenida a bordo del tren (símbolo así mismo de tránsito, progreso y modernidad) constituirá el necesario rito de paso para que la nación supere sus lastres y pueda prosperar. Un cambio en la mentalidad de la sociedad española, que demuestre su capacidad para integrar en su seno a la totalidad de sus habitantes, será la locomotora que conduzca al país hacia un mañana mejor, dejando atrás el sombrío pasado reciente del país y la división social. ${ }^{7}$ Como afirmó Minguet Batllori, los dramas de los personajes de Nieves Conde «pretenden convertirse en proverbio, en moraleja socializante». ${ }^{8}$ El programático discurso responde a la firme concepción que el director segoviano poseía del cine como transmisor de ideología y de valores, al tiempo que, en su obvia discursividad, lo vincula con el falangismo progresista del cineasta, condicionante decisivo de su obra durante el período en el que filma Todos somos necesarios, pues la integración político-social de los españoles era una de la consignas del falangismo, así como el carácter interclasista del nacionalismo que propugnaba como estrategia para superar la conflictividad social con que amenazaba el desarrollo político del movimiento obrero.

6 Nieves Conde recupera el tema del éxodo rural de Surcos, pues esta familia se traslada desde su pueblo hacia Avilés, en cuya factoría el padre aspira a trabajar.

7 En una entrevista realizada antes del estreno del filme, el director lo definía como «una llamada a la solidaridad humana», que entroncaba con Surcos, pero cuya «visión» era «más poética y optimista». Barreira (1956). «Con quince preguntas basta. Contesta José Antonio Nieves-Conde». Primer Plano, $\mathrm{n}^{\circ}$ 814. año XVI.

8 Minguet Batllori, Juan M. (2003). «Proverbios y moralejas: Surcos (1951), Todos somos necesarios (1956)», en José Luis Castro De Paz y Julio Pérez Perucha (eds.). Tragedia e ironía: el cine de Nieves Conde. Ourense: Caixa Galicia, Festival de Cine Internacional de Ourense, p. 42. 


\subsection{Liberalismo}

A esa raíz falangista del discurso articulado por el presente largometraje debemos acudir para hallar las razones de la peyorativa caracterización del personaje de Marcos Alberola (Rolf Wanka), empresario adinerado perfilado maniqueamente a partir de rasgos esencialmente negativos. Alberola representa a esa nueva burguesía fruto del capitalismo contra el que se levantaba la Falange. El décimo punto del programa ideológico que la Jefatura de la Falange Española de las J.O.N.S. hizo público en las páginas del diario $\mathrm{ABC}$ exponía su repudia del «sistema capitalista, que se desentiende de las necesidades populares, deshumaniza la propiedad privada y aglomera a los trabajadores en masas informes, propicias a la miseria y a la desesperación». ${ }^{9}$ Así mismo, un notorio falangista como José Luis de Arrese, ministro de Vivienda, condenaba explícitamente al capitalismo, al que consideraba el mayor pecado de los tiempos modernos. ${ }^{10}$

En su presentación, sentado junto a otros compañeros de viaje en el vagón restaurante, Marcos se revela como un ciudadano dominado por sus prejuicios: pese a dejar claro que es «extraordinariamente liberal», se queja de que «su» tren se haya detenido en una estación «donde solo suben y bajan criminales», lamentando verse obligado a mezclarse con ellos. «Son seres humanos, como usted y como nosotros», alega uno de los contertulios. Marcos, manifestando una palpable indignación, se afana en aclarar que no mantiene «ningún parecido con tipos así». Otro de los presentes, Enrique Espinosa (Rafael Durán), añade: «Hay muchos más ladrones y asesinos sueltos que encerrados». El diálogo concluye con la intervención de un policía que apunta: «Si nos diesen la orden de detener a muchos que pasan por hombres de negocios y que no son más que estafadores y ladrones vulgares, haríamos horas extraordinarias». La conversación escuetamente descrita establece un vínculo entre el personaje de Marcos (y, por extensión, todo aquel que esconde su corrupción moral y/o actividades delictivas bajo una fachada de respetabilidad) y la falsedad de las apariencias, que apunta a la naturaleza perniciosa de todos aquellos ciudadanos a los que representa mediante su caracterización arquetípica, confeccionada a partir de la aglomeración de rasgos negativos que aluden a su superficialidad, materialismo - «Para ti solo existe una realidad: el dinero. Lo demás no cuenta», le dice su esposa, Laura (Lída Baarová) - y falsedad, así como a su incapaz de establecer lazos sinceros con ninguna otra persona - es infiel a su mujer con su secretaria, Elena (Josefin Kipper)-. Es por ello que el personaje termina abandonado a su (mala) suerte por el enunciador: separado de su cónyuge e hijo y rechazado por su secretaria, quien opta por iniciar una relación con Julián.

Personificación del capitalismo, Marcos es un agente pernicioso, capaz de truncar la clave tonal de una secuencia con su entrada en escena. Veámoslo. Julián confiesa a Nicolás que, tras realizar la imprevista operación del menor, se ha liberado de la losa que sobre él pesaba figuradamente a causa de su inhabilitación como cirujano (volveremos sobre esta conversación más adelante). La conversación es resuelta por el realizador mediante la consabida técnica del plano-contraplano, respetando el normativo eje de miradas de ciento ochenta grados entre ambos conter-

9 «El programa de Falange Española de las J.O.N.S.», ABC, número 9.834, año 30, viernes 30 de noviembre de 1934, pp. 32-34.

10 Payne, Stanley G. (1985). Falange: Historia del fascismo español. Madrid: Sarpe, p. 237. 
tulios. Será la llegada de Marcos al espacio y su incorporación al diálogo la que provoque que la cámara traspase el eje de ciento ochenta grados establecido para alojar en el campo visual al incorporado personaje, mostrando el espacio que antes quedaba tras la cámara, pues es ahí donde toma asiento el empresario. Este gesto no tendría mayor importancia (posee su lógica en la realización) si la trasgresión del eje (que se efectúa tras pasar por un plano general que muestra cómo Marcos entra en el vagón, limando la ruptura del eje previamente instaurado) no conllevase también, como si fuera resultado de ésta, el final de la positividad de la secuencia, dando paso nuevamente a tensiones interpersonales fruto de los prejuicios del capitalista. [Figs. 7 a 10].
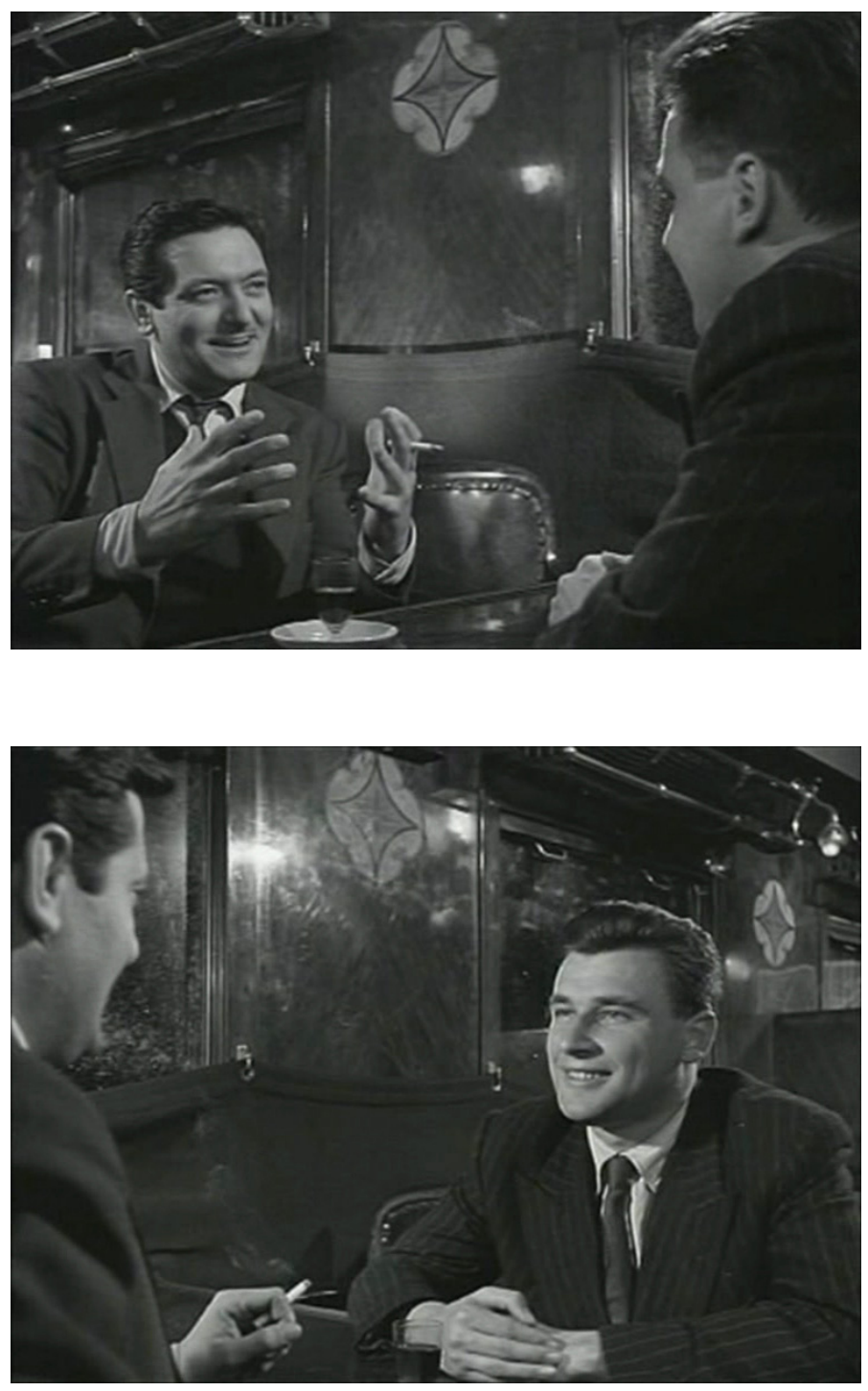

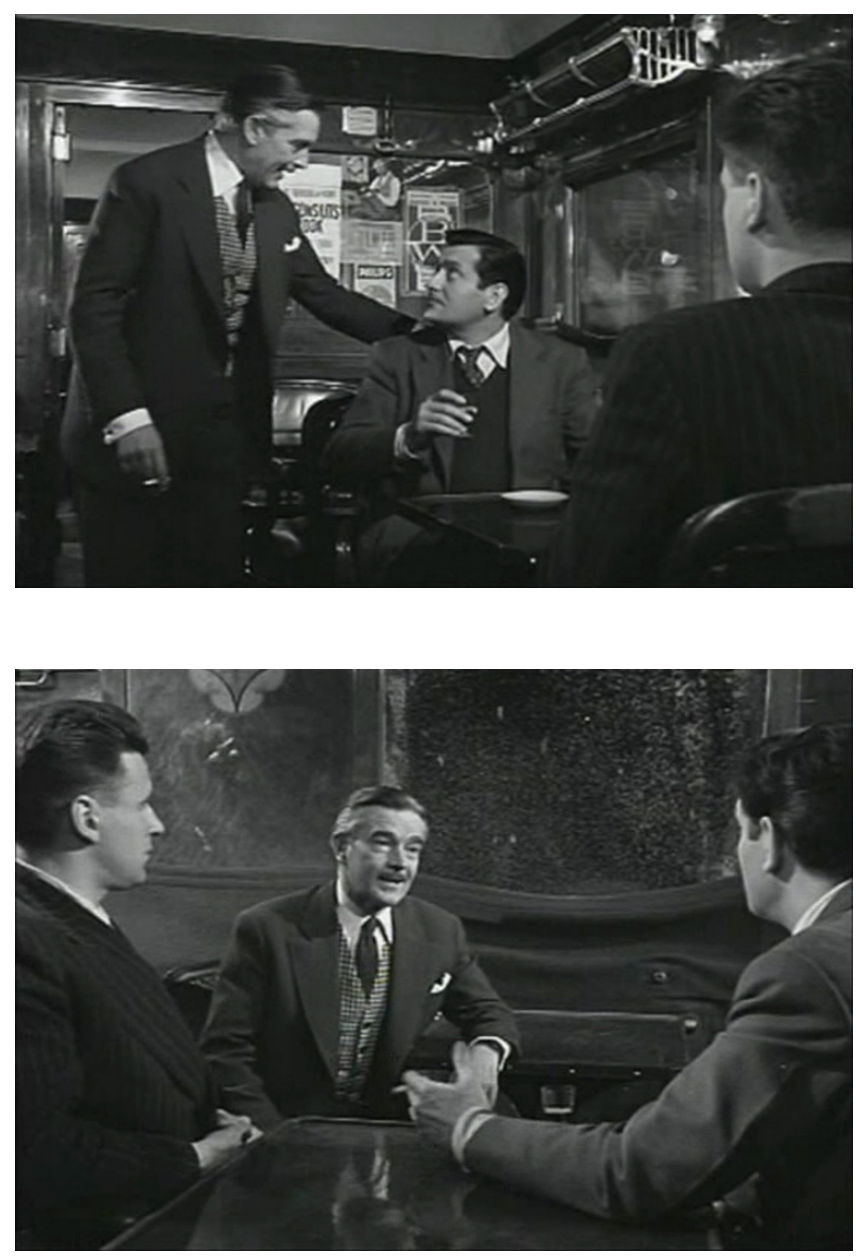

En una sociedad regida por los prejuicios y las apariencias, el dinero constituye una garantía de acceso a la respetabilidad social. Así lo cree Nicolás tras salir del penal, desencantado con el mundo: «No hay otra moral que la que se encierra en una caja registradora. Lo demás son tonterías», afirma. Esta tesis será, empero, desarticulada por el filme, pues serán sus acciones las que determinen la (re)integración de los personajes en la sociedad y la reparación de la honra. En este sentido, Todos somos necesarios se revela construida en torno al concepto de dignidad: mientras que unos luchan por mantenerla o recuperarla (el trío de expresidiarios), otros la pierden por sus prejuicios y conducta reprobable (Marcos).

\subsection{Sacrificios por el bien de la comunidad}

De entre el trío de expresidiarios, el filme otorga una mayor entidad dramática al personaje encarnado por Alberto Closas, Julián Martínez Valdés, antiguo cirujano inhabilitado y condenado a seis años de prisión a causa de la muerte de un paciente desahuciado al que intentó salvar obviando el noventa por ciento de posibilidades en contra del éxito que la intervención quirúrgica tenía. Pese a la coralidad del relato, es 
en torno a este personaje sobre el que pivota el conflicto dramático esencial del filme. La necesidad de someter a un niño con difteria a una operación en el interior del tren, que permanece detenido por acumulación de nieve en las vías, traza, junto con la biografía pasada del personaje, el conflicto íntimo que este habrá de afrontar, pues realizar la operación del inocente podría implicar su regreso a prisión al no respetar su inhabilitación profesional. Tras el rechazo inicial, el cirujano asume su responsabilidad moral e interviene al pequeño, en una decisión que implica el sacrificio por el prójimo y por el bien de la comunidad, así como la purga del pecado pasado, que posibilita la superación del temor a la responsabilidad de la muerte de su paciente anterior. El personaje dejará atrás de este modo su resentimiento inicial para con la sociedad y ésta retribuirá su sacrificio reintegrándolo en su seno.

El climático instante en que Julián asume el mando de la operación se construye mediante una tan habitual como eficiente estrategia narrativa generadora de suspense. El protagonista se halla en un vagón distante a aquel en el que se prepara la intervención. Inquieto por su conciencia, empieza a atravesar los vagones que median entre su ubicación y el espacio de la inminente operación con el objeto de intentar llegar a tiempo para encargarse de ésta. La cámara acompaña al personaje mediante un travelling horizontal que es aderezado con una estridente música (cuyo ritmo se incrementa al tiempo que la tensión aumenta y la escala del plano se reduce) y un montaje que muestra alternativamente el avance de Julián y la inminencia del comienzo de la operación para generar angustia y suspense en el espectador ante la contingencia de que el personaje no llegue a tiempo de salvar al niño. Nos encontramos, pues, ante la mecánica narrativa prototípica de la salvación en el último segundo.

En el instante en que el protagonista inicia la operación, un plano trunca la sobriedad formal del filme. En una imagen filmada con un angular, Julián mira directamente a cámara y dirige el bisturí hacia ella, de manera que parece seccionar su objetivo. La cámara asume el lugar de la herida dramática del personaje. Este gesto, que parece cortar el ojo del espectador, marca un cambio en la manera en que el personaje será visto por el resto de pasajeros del tren, justificado dramáticamente por el satisfactorio resultado de la intervención quirúrgica, que, no obstante, encontrará un temprano y abrupto final cuando se conozca la noticia del robo de la cartera de Marcos por parte de Iniesta. [Figs. 11, 12].

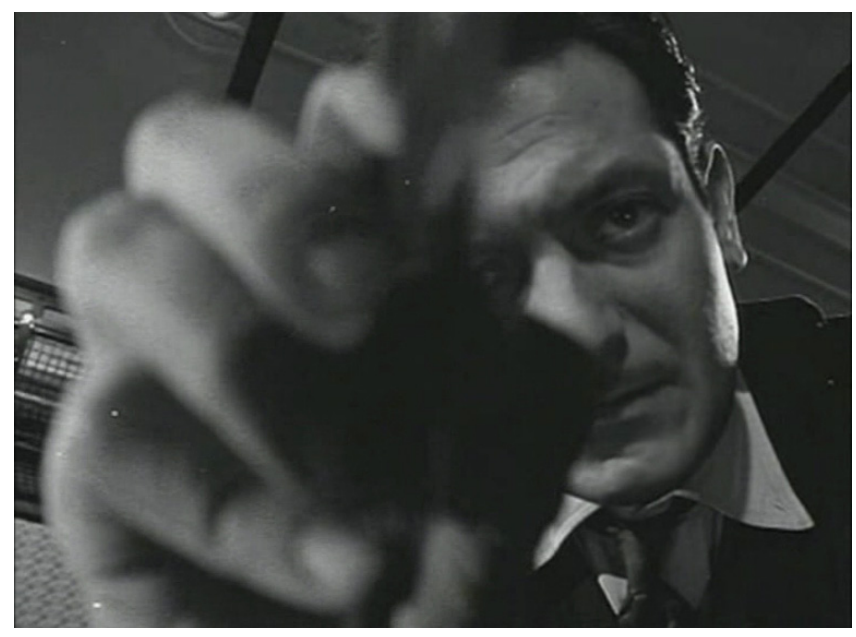




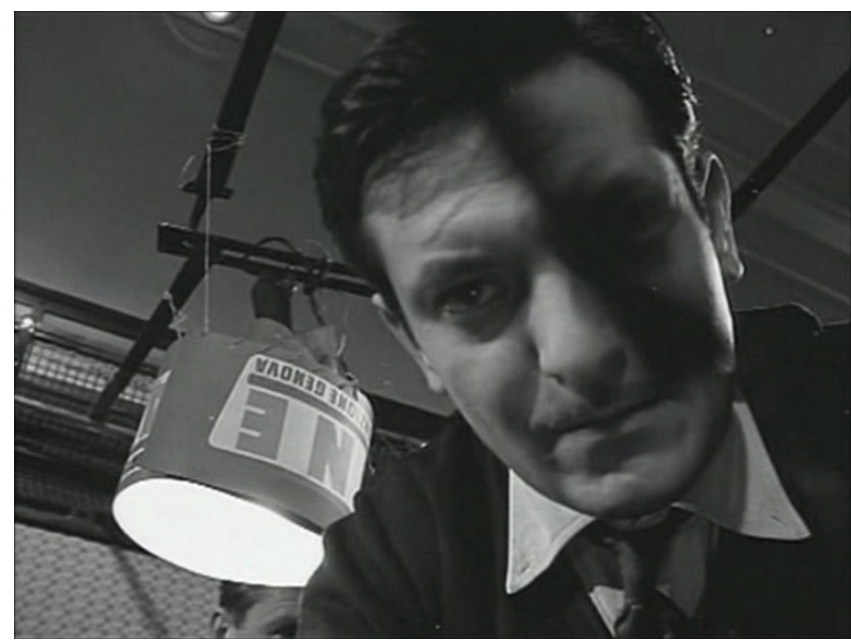

En los últimos compases de la operación, la enunciación prioriza la reacción de los pasajeros que han sido testigos de ésta; entre ellos, el misionero, cuyos ojos son resaltados mediante un punto de luz antes de que los cierre (probablemente para agradecer al Señor la salvación del pequeño). La relevancia que se otorga a las reacciones y miradas de estos personajes, así como la nula importancia que, por contra, se dispensa a la del cirujano, encuentran su explicación en la finalidad dramática de tal proceder: justificar el cambio de actitud de los viajeros para con los presidiarios («No serán tan malos», afirmará uno de los pasajeros). Así mismo, la espiritualidad que emana el presente instante radica, de nuevo, en su raíz falangista, pues la religión católica representaba una parte esencial de la idiosincrasia nacional de la sociedad española según Falange Española. [Fig. 13].

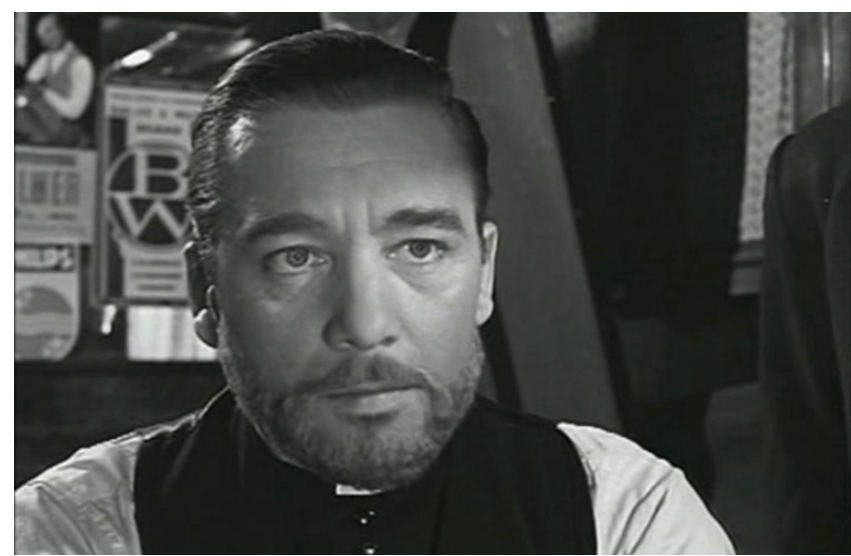

Pese a todo, un nuevo giro de guion viene a perturbar tan idílica resolución: la sustracción de la cartera propiedad de Marcos, presuntamente obra de Iniesta. Será nuevamente el sacrificio del personaje, que decide inmolarse para intentar llegar a la estación más próxima para salvar al inocente niño, lo que le redima y clausure los conflictos dramáticos generados entre ambos grupos. Así, los pasajeros superarán finalmente sus prejuicios iniciales y la pareja formada por Nicolás y Alicia podrá 
proseguir conjuntamente su vida y dejar atrás el pasado (reconciliación matrimonial que es sellada con un plano de detalle de sus manos cogiéndose). La planificación refleja la unión final de todos los personajes retratándolos mediante planos de conjunto en el interior de la estación, certificando la superación de las barreras ideológicas y de clase que los separaban.

En la estancia contigua, Iniesta recibe la extremaunción. Su redención es explicitada verbalmente: «Es la primera vez que salgo absuelto», afirma tras recibir el viático. Un plano contraplano entre el ex presidiario y el sonriente niño por cuya salvación ofreció la vida rubrica la resolución del conflicto. Sobre el final de su película, afirmaba el cineasta: «Los últimos planos de Folco Lulli y el tren alejándose simbolizan una nueva posibilidad humana», ${ }^{11}$ la esperanza de un futuro integrador para todos al haber dejado atrás el colectivo protagonista los prejuicios. [Figs. 14 a 16].
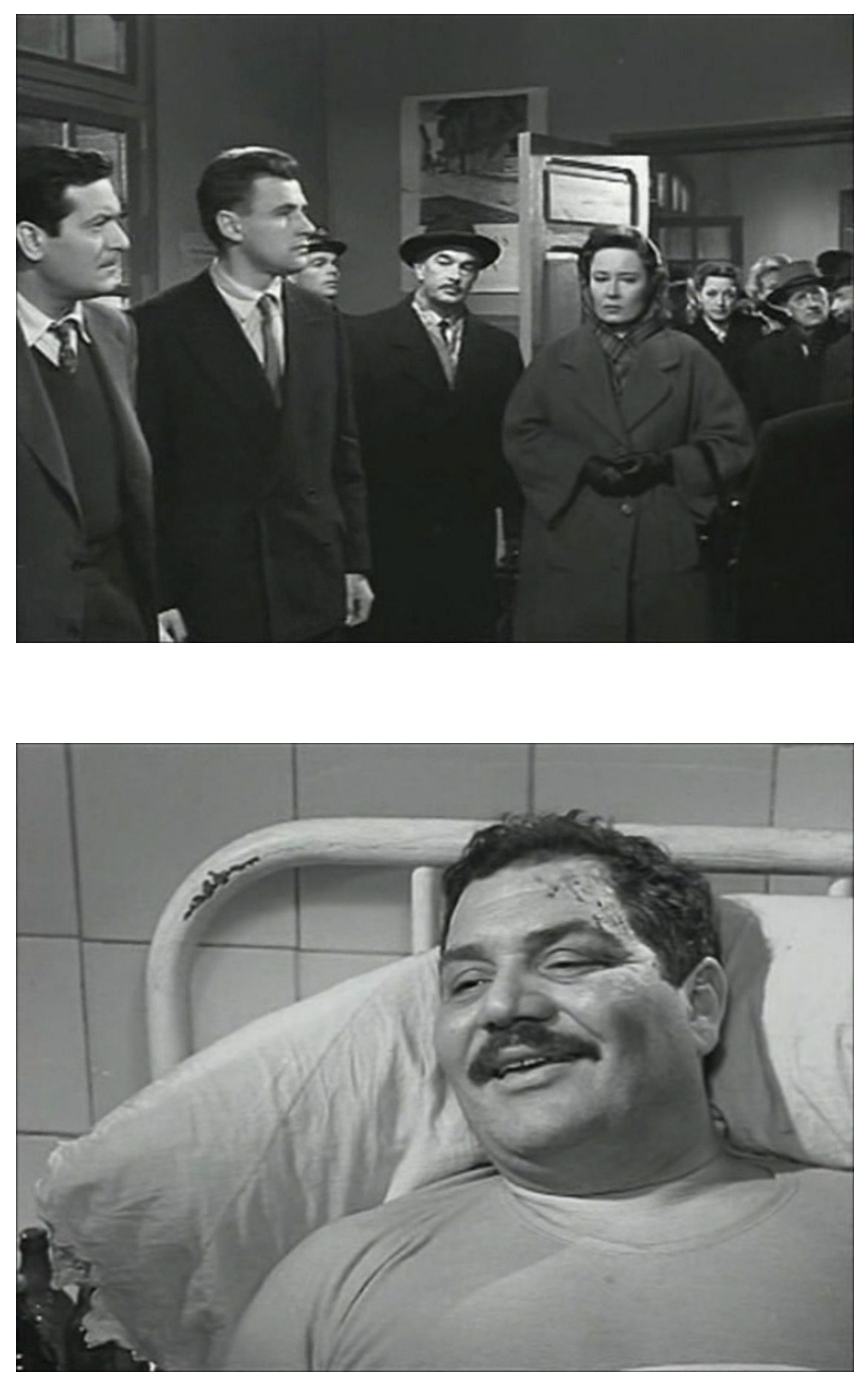

$11 \quad$ Llinás, 1995: 99. 


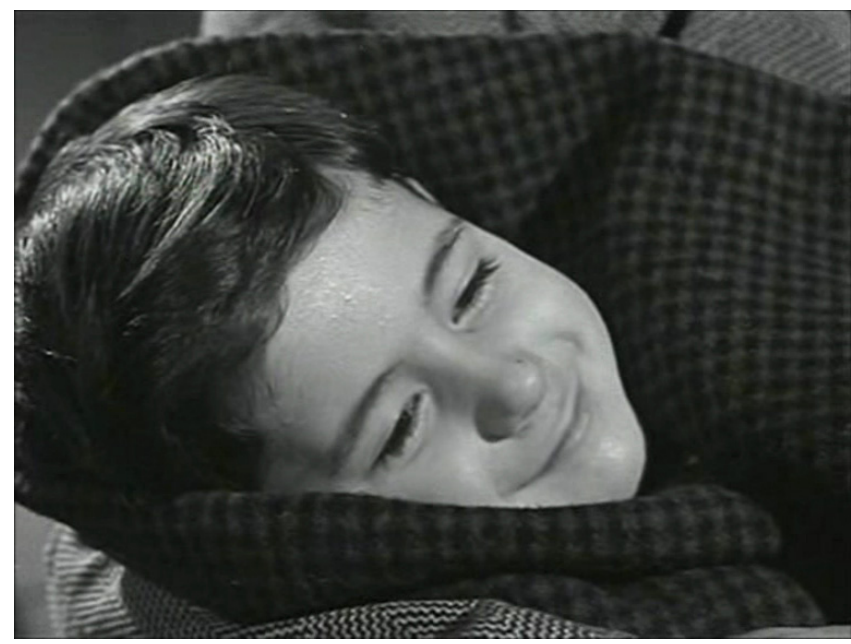

\subsection{Redundancia}

A pesar de la efectividad de los dispositivos retóricos y expresivos que el enunciador moviliza, el filme evidencia su discurso mediante el recurso a la palabra en no pocos instantes. Es por ello que Todos somos necesarios termina convirtiéndose en una obra en la que por momentos se produce una notoria redundancia discursiva entre las bandas de sonido y de imagen. Veamos un breve ejemplo. Julián ha rechazado realizar la intervención quirúrgica que podría salvar la vida del niño enfermo, pues hacerlo implicaría violar la inhabilitación profesional a la que fue condenado. El misionero asume tal responsabilidad, aunque sus conocimientos de medicina son limitados. Un grupo de pasajeros se traslada junto con el infante al vagón comedor para proceder a realizar la operación. Julián, por su parte, se dirige en dirección contraria a dicho vagón, alejándose del lugar en el que se desarrollará la intervención. La dirección de su desplazamiento se contrapone con la de los demás personajes, que buscan entre sus propiedades cualquier elemento que pueda ser de utilidad en la intervención. Al toparse Julián con uno de estos pasajeros, este le recrimina: «¿Por qué no se fija? Va usted en contra de todo el mundo», evidenciando no solo la oposición en el movimiento entre el personaje del médico y el resto de actantes, sino la circunstancia dramática de que el primero se haya mantenido al margen de ese objetivo común (la salvación del pequeño mediante la operación) que cohesiona al resto.

En otro instante del filme, es el propio personaje quien explicita verbalmente su evolución dramática, cuando, exultante tras el éxito de la intervención, Julián confiesa a Nicolás: «Acabo de abrir las puertas de mi cárcel, Nicolás. Mis manos están libres. Antes estaba desesperado porque creí que nunca más volvería a ser lo que fui. Estaba equivocado. Ahora ya no seré médico, pero por mi propia voluntad. Algún día había que romper con el pasado y empezar de nuevo a vivir».

En consecuencia, los diálogos y las situaciones dramáticas del filme parecen responder (en ocasiones, de manera forzada) a una finalidad didáctica e ilustradora de su tesis. Este afán explicitador del discurso es claramente perceptible desde su propio título, que enuncia con total literalidad la moraleja que puede extraerse de su visionado, fijando el sentido de la lectura del espectador. 


\section{Conclusiones}

Los personajes del cine de Nieves Conde vinculado a cuestiones sociales trascienden la singularidad de su caracterización para constituirse en representantes metonímicos del colectivo y la clase social a la que pertenecen: la familia Pérez de Surcos, el Evaristo González de El inquilino (nótese los muy comunes apellidos de los protagonistas, que señalan la clara voluntad de evitar la singularización por parte del responsable de ambos filmes) o los diversos sujetos que viajan en el tren que acoge la trama de Todos somos necesarios representan tipos concretos de ciudadanos de la España de la época sobre cuya caracterización, comportamiento y objetivos ejerce un determinismo concluyente la clase social a la que pertenecen. Sus peripecias dramáticas reflejan aquellas que cualquier individuo perteneciente al mismo estrato social podría experimentar en la España de mediados del siglo XX.

Sus protagonistas luchan por encontrar un espacio vital, afectivo, doméstico y/o laboral que asegure y satisfaga sus necesidades vitales. La familia labriega de Surcos abandona su hábitat rural para trasladarse a Madrid en una infructuosa búsqueda de trabajo y porvenir, el trío protagonista de Todos somos necesarios encuentra dificultades para reinsertarse en la sociedad a su salida de presidio y Evaristo es obligado a abandonar su hogar para quedar viviendo a la intemperie junto con su familia. La búsqueda de una dignidad personal late en los conflictos dramáticos planteados en este trío de filmes.

Por ello, la ubicación de los personajes en el campo visual traduce en términos visuales la integración o marginalidad de los caracteres, amén de los conflictos existentes entre ellos. La planificación de Todos somos necesarios subraya inicialmente la individualidad de algunos personajes para, posteriormente, integrarlos en planos de conjunto que los ponen en relación directa con el resto de pasajeros, planteando a través de la composición la necesidad de colaboración colectiva que vehicula la trama, así como con el espacio en el que se encuentran; es decir, con el contexto social que los define y, a un mismo tiempo, condiciona.

Por último, en Todos somos necesarios encontramos un enunciador que adjetiva y comenta las situaciones dramáticas mediante dispositivos formales y retóricos dotados en ocasiones de una notoria violencia enunciativa que inscribe la evidencia de esa instancia enunciativa en la materialidad de los textos. A tenor de lo expuesto en nuestro trabajo, podemos concluir que las opciones formales de las que Nieves Conde se sirve para articular el texto fílmico mantienen una coherencia plena con respecto a su discurso. Este sincretismo de elementos temáticos y formales (la complementariedad y sinergia entre expresión y contenido) es una característica definitoria de toda su obra, incluso en los proyectos alimenticios y de encargo que monopolizarán su producción a partir de la década de los sesenta. Se opera así una configuración y articulación del significante encauzada hacia su eficiencia discursiva, al tiempo que un programa formal de meditada disidencia político-ideológica mediante la edificación de una imagen semánticamente cargada para aproximarse críticamente a una realidad social y económica determinada.

\section{Bibliografía}

Barreira (1956). «Con quince preguntas basta. Contesta José Antonio Nieves-Conde». Primer Plano, $\mathrm{n}^{\circ}$ 814. año XVI. 
Heredero, Carlos F. (1993). Las huellas del tiempo. Cine español, 1951-1961. Valencia: Filmoteca de la Generalitat Valenciana / Filmoteca Española.

Hjelmslev, Louis (1971). Prolegómenos a una teoría del lenguaje. Madrid: Gredos.

Llinás, Francisco (1995). José Antonio Nieves Conde. El oficio de cineasta, Valladolid: Seminci.

Minguet Batllori, Juan M. (2003). «Proverbios y moralejas: Surcos (1951), Todos somos necesarios (1956)», en José Luis Castro De Paz y Julio Pérez Perucha (eds.). Tragedia e ironía: el cine de Nieves Conde. Ourense: Caixa Galicia, Festival de Cine Internacional de Ourense, pp. 31-42.

Payne, Stanley G. (1985). Falange: Historia del fascismo español. Madrid: Sarpe.

Rodríguez Jiménez, José Luis (2000). Historia de Falange Española de las JONS. Madrid: Alianza. 